\title{
BIOMECHANICAL PROPERTIES OF THE TERRESTRIAL MOSSES PLEUROZIUM SCHREBERI (BRID.) MITT. AND POGONATUM JAPONICUM SULL. \& LESQ. ALONG ALTITUDINAL GRADIENTS IN NORTHERN JAPAN \\ БИОМЕХАНИЧЕСКИЕ СВОЙСТВА НАЗЕМНЫХ МХОВ PLEUROZIUM SCHREBERI (BRID.) MITT. И РOGONATUM JAPONICUM SULL. \& LESQ. ВДОЛЬ ВЫСОТНОГО ГРАДИЕНТА В ГОРАХ СЕВЕРА ЯПОНИИ
}

\author{
HEINJO J. DURING ${ }^{1}$, BETTY VERDUYN ${ }^{1} \&$ ANNIKA K. JÄGERBRAND ${ }^{2}$ \\ ХЕЙНИО Й. ДЮРИНГ ${ }^{1}$, БЕТТИ ВЕРДУЙН ${ }^{1}$, АННИКА К. ЯГЕРБРАНД ${ }^{2}$
}

Abstract

\begin{abstract}
Altitudinal gradients along mountain slopes provide valuable opportunities to study variation in plant traits in response to changes in environmental conditions along such gradients. This study focused on biomechanical traits of two moss species, the more or less horizontally growing Pleurozium schreberi and the erect-growing Pogonatum japonicum, along altitudinal gradients on two mountains in Hokkaido, northern Japan. We measured stem diameter in two directions to determine the second moment of area I, used three-point bending tests with free stem ends to determine the slope of the force-deflection curve $\mathrm{dF} / \mathrm{dx}$, and used these data to calculate Young's modulus and flexural rigidity of the stems. Both species showed much variation in all traits among replicates in the samples at each altitude. Environmental variation associated with altitude had more effect on the biomechanical traits of $P$. japonicum than on those of $P$. schreberi. Stems of $P$. japonicum were thicker (larger I) than those of $P$. schreberi and had a larger Young's modulus and flexural rigidity. Stems tended to become thinner (lower second moment of area) and less rigid (lower flexural rigidity) at increasing altitude in both species.
\end{abstract}

Резюме

Высотный градиент в горах дает значительные возможности изучения признаков растений в ответ на меняющиеся условия среды вдоль этого градиента. Исследование в данном случае концентрировалось на биомеханических свойствах двух видов мхов, преимущественно плагиотропного Pleurozium schreberi и б.ч. прямостоячего Pogonatum japonicum. Работа проведена на склонах двух гор на Хоккайдо, Япония. Был измерен диаметр стебля в двух направлениях для определения второго момента площади I, с использованием теста на сгиб по трем точкам, причем концы стебля не были закреплены с целью определить зависимость отклонения кривой $\mathrm{dF} / \mathrm{dx}$, и рассчитать модуль Юнга (упругости стебля при растяжении) и упругости стебля на сгиб. Оба вида оказались сильно вариабельными по всем изученным признакам в выборках с отдельных высот. Зависимость от высоты произрастания растений у P. japonicum оказалось более явной, чем у P. schreberi. Стебли P. japonicum были толще, чем у P. schreberi и имели больший модуль Юнга и упругости на сгиб. Стебли имеют тенденцию к истончению (имеют более низкий второй момент площади) и становятся менее жесткими (с более низким значением упругости на сгиб) с увеличением высоты для обоих видов.

KEYWORDS: bryophytes, stem, flexural rigidity, altitudinal traits, Pleurozium, Pogonatum

\section{INTRODUCTION}

Many bryophyte species occur over a range of environments and show variation in their morphology, anatomy and physiology in response to differences in environmental factors along this range. A prime example of such a range is the altitudinal gradient along mountain slopes. This inherently involves a gradient of atmospheric pressure and temperature, although many other factors important for plant life such as moisture and soil development usually also show clear trends (Körner, 2007). Many studies have found both genetically and plastically determined changes in traits relevant for photosynthetic performance and water economy of vascular plants (e.g., Körner et al., 1986), including patterns of biomass allocation to stems and roots and root length / leaf area ratios (Körner \& Renhardt, 1987). Bryophytes may be expected to show similar patterns, and have done so in some studies (Waite \& Sack, 2011), while other studies have shown variation in photosynthesis, respiration and desiccation tol-

1 - Ecology and Biodiversity group, Institute of Environmental Biology, Utrecht University, H.R. Kruyt Building, P.O. Box 800-84, 3508 TB Utrecht, The Netherlands; e-mail: h.j.during@uu.nl, g.p.verduyn@uu.nl

2 - Faculty of Environmental Earth Science, Hokkaido University, Sapporo 060-0810, Hokkaido, Japan; Current address: The Swedish National Road and Transport Research Institute, Box 55685, SE-102 15 Stockholm, Sweden; E-Mail: annika.jagerbrand@vti.se 
erance hardly related to altitude (Bader et al., 2013; Wagner et al., 2013).

Other physical factors affecting plants, such as snow load, will also vary with altitude, yet biomechanical traits have seldom been studied in relation to altitude. In one of the few existing studies, Eldar pine (Pinus eldarica Medw.) showed considerable variation in wood mechanical properties along a gradient from 500 to $1400 \mathrm{~m}$ a.s.l. in northern Iran (Kiaei \& Samariha, 2011). Biomechanical properties of bryophytes along altitudinal gradients have not yet been studied, although a study of the mechanical properties of two growth forms of Hylocomium splendens (Hedw.) Schimp. (Ross et al., 1998), one from low-arctic and one from high-arctic conditions, suggests that these traits may also show considerable variation along elevational gradients.

There are only a few studies on the biomechanics of bryophytes in general, perhaps partly because of their small size and often dense canopies, as a result of which strong mechanical forces due to wind are not likely to play a significant role. Yet Niklas (1993, 1994, 1995) showed that the biomechanical properties of moss stems fitted the general allometrical scaling relationships found for vascular plants very well. Sympodial and monopodial plants of the large, usually weft-forming pleurocarpous moss Hylocomium splendens originating from lowarctic and high-arctic conditions, respectively, differed markedly in the mechanical properties of their stems (Ross et al., 1998). Sympodial plants annually produced a new, initially vertically oriented, stem segment from a meristem on a stem segment of the previous year. Over a period of ca 1.5 year, the new segments branched extensively while gradually changing growth direction from vertical to almost horizontal. After another two years or so, the segments gradually senesced. Over this period the stems gradually became thinner but the material of which they were made became stiffer (higher Young's modulus), and the stem diameter gradually decreased. As a consequence, the stiffness (flexural rigidity) of the stems first increased and after 4-5 years decreased again. Plants with monopodial shoots were usually prostrate, and their stems were thinner and less stiff than those of sympodial plants, with hardly any change over the years. These results were interpreted as a trade-off beween the benefits of vertical growth in terms of light interception and associated carbon gain and the costs of the tissues needed for support (following Givnish, 1986), and as showing that the sympodial plants were mechanically adapted to carry at least their own weight (Ross et al., 1998). Transplant studies showed that the difference in growth form was largely a plastic response but probably also genetically determined to some extent (Ross et al., 2001).

The work of Biehle et al. (1998) on the aquatic species Fontinalis antipyretica Hedw. demonstrated the remarkable strength of its stems and showed that variation in its mechanical properties (due to variation in the relative proportion of strengthening tissue in the cortex of the stems) corresponded with the water velocity at the places where the plants were growing.

Finally, Frenzke et al. (2011) showed how similar levels of mechanical strength may be achieved using different anatomical designs by comparing the mechanical properties of the tall Polytrichaceous moss Dendroligotrichum dendroides (Hedw.) Broth. with those of vascular plants and the few other bryophyte species that have been studied. Detailed anatomical analyses of the conducting tissues in the stem of this species suggested that $D$. dendroides is subject to similar biomechanical constraints as tracheophytes (Atala \& Alfaro, 2012).

In this paper we report on a study of biomechanical properties of stems of two bryophyte species differing in growth-form along a gradient of environmental harshness as represented by altitudinal gradients on Mt. Oakan and Mt. Teshio (Japan). Pogonatum japonicum Sull. \& Lesq. produces tall turfs (sensu Gimingham \& Birse, 1957) of leafy, unbranched stems which are usually vertically oriented and anatomically similar to those of $D$. dendroides studied by Frenzke et al. (2011) and Atala \& Alfaro (2012), while the stems of Pleurozium schreberi (Brid.) Mitt. are much more branched and grow more horizontally to produce dense 'wefts', somewhat like the prostrate form of $H$. splendens studied by Ross et al. (1998). The stands of P. schreberi consisted of several genotypes each and there was clear evidence of genetic differentiation between altitudes (Korpelainen et al., 2012). An ecophysiological study on thermal acclimation of photosynthesis and growth in the same species in the same zones on Mt. Oakan showed that stands differed in response to temperature, but did not show consistent trends with altitude (Jägerbrand et al., 2014). Based on the assumption that stems may be just as strong and thick as needed in the particular environment in which they are growing, we tested the following hypotheses:

1) Biomechanical tissue properties such as Young's modulus vary consistently along an altitudinal gradient for both species;

2) An erect-growing species will have a higher Young's modulus and flexural rigidity than one with more horizontally growing stems.

\section{MATERIAL AND METHODS}

\section{Collection of samples}

Pleurozium schreberi samples of approximately 10 $\mathrm{cm}$ diameter were collected from 10 sites along an altitudinal gradient from 460 to $1350 \mathrm{~m}$ a.s.l. at Mt Oakan $\left(43^{\circ} 45^{\prime} \mathrm{N}, 144^{\circ} 16^{\prime} \mathrm{E}\right)$ (Table 1) on 29-30 June 2007. Where possible, from these samples 20 stems with a length of at least $4 \mathrm{~cm}$ were selected, but in most cases the actual number of available stems was slightly lower (Table 1). Almost all shoots sampled at $545 \mathrm{~m}$ a.s.l. were too short to be used in the tests, and this sample 
Table 1. Summary of mechanical properties of Pleurozium schreberi on Mt. Oakan, Hokkaido, Japan (averages \pm S.E.). E: Young's modulus; I: second moment of area; E*I: flexural rigidity.

$\begin{array}{lllll}\text { Alt }(\mathrm{m} \text { asl }) & \text { \#replicates } & \mathrm{E}(\mathrm{MPa}) & \mathrm{I}\left(\mathrm{mm}^{4}\right) & \left.\mathrm{E} * \mathrm{I}(\mathrm{N} \mathrm{mm})^{2}\right) \\ 460 & 19 & 604 \pm 91 & 0.0028 \pm 0.0004 & 1.516 \pm 0.274 \\ 670 & 20 & 662 \pm 119 & 0.0016 \pm 0.0002 & 0.757 \pm 0.122 \\ 750 & 19 & 651 \pm 99 & 0.0016 \pm 0.0002 & 0.911 \pm 0.151 \\ 870 & 15 & 759 \pm 117 & 0.0013 \pm 0.0002 & 0.803 \pm 0.183 \\ 965 & 19 & 732 \pm 130 & 0.0012 \pm 0.0001 & 0.739 \pm 0.093 \\ 1055 & 17 & 724 \pm 156 & 0.0011 \pm 0.0003 & 0.487 \pm 0.06 \\ 1185 & 17 & 572 \pm 112 & 0.0016 \pm 0.0002 & 0.77 \pm 0.162 \\ 1260 & 10 & 978 \pm 115 & 0.0003 \pm 0.00003 & 0.323 \pm 0.047 \\ 1350 & 19 & 635 \pm 61 & 0.0012 \pm 0.0001 & 0.714 \pm 0.073\end{array}$

was therefore excluded. Pogonatum japonicum was collected at 8 sites on Mt Eniwa $\left(42^{\circ} 47^{\prime} \mathrm{N}, 141^{\circ} 28^{\prime} \mathrm{E}\right)$ on 15-24 August 2006 along an altitudinal gradient from 320 to 1219 m a.s.1. (Table 3), in Hokkaido, Northern Japan. At each site samples were carefully collected a few $\mathrm{m}$ apart, ensuring that the moss stems were not damaged. The collected samples were approximately 10 $\mathrm{cm}$ in diameter, and the number of samples used from each site varied depending on the number of sufficiently long (over $4 \mathrm{~cm}$ ) stems available (see Table 3). At Mt Oakan, Pleurozium schreberi occurred in the understory of coniferous forests and at higher altitudes beneath shrubs (e.g., Pinus pumila (Pall.) Regel). At Mt Eniwa, Pogonatum japonicum grew in the understory of mixed forest, for example comprising oak, ash and conifers, from the lowest to the highest altitudes. After collection, the samples were dried and sent to Utrecht. There they were kept dry until the study of their mechanical properties in 2008.

\section{Mechanical properties}

Stems with lengths of at least $3 \mathrm{~cm}$ were carefully remoistened by spraying with tap water and kept in plastic bags until the measurement, which took place within a period of one hour.

To address our hypotheses we focused on Young's modulus (E), obtained from measurements of the force needed to bend the stems. We used a 3-point bending test with free stem ends, as the results of this method are most likely to allow interpretation in terms of resistance against mechanical failure in the field (Ross et al., 1998). In order to keep the ratio of span L over diameter D above 20 to minimize effects of shear (Ross et al., 1998), we used a span of 2 or, if possible, $3 \mathrm{~cm}$, as stem diameter did not exceed $1 \mathrm{~mm}$. Tests were carried out with an Instron 5542 universal testing machine with a sensitive load cell (maximum force $5 \mathrm{~N}$ ). This measured the applied force $F$ (in $\mathrm{N}$ ) and the extension $\mathrm{x}(\mathrm{mm})$. After measurement we determined stem radius $\mathrm{r}(\mathrm{mm})$ of the material while still fresh by measuring the diameters of cross sections in two directions under a microscope.

After plotting force $\mathrm{F}$ against extension $\mathrm{x}$ we calculated (or estimated from the graph) the initial gradient of the force-deflection curve $\mathrm{dF} / \mathrm{dx}$. Using this value, we calculated the flexural rigidity (a stem property, dependent on span $\mathrm{L}$ and radius $\mathrm{r}$ ):

Flexural rigidity $\mathrm{E}_{\mathrm{b}} \mathrm{I}=\mathrm{L}^{3}(\mathrm{dF} / \mathrm{dx}) / 48$

Where I represents the second moment of area.

From this formula, Young's modulus $\mathrm{E}_{\mathrm{b}}$ was calculated:

$\mathrm{E}_{\mathrm{b}}=\mathrm{L}^{3}(\mathrm{dF} / \mathrm{dx}) / 48 \mathrm{I}=\mathrm{L}^{3}(\mathrm{dF} / \mathrm{dx}) /\left(12 \pi \mathrm{r}^{4}\right)$

Often the stem cross section was elliptical rather than round, in which case we determined short and long radii $r_{a}$ and $r_{b}$, respectively, and used the formula:

$$
\mathrm{E}_{\mathrm{b}}=\mathrm{L}^{3}(\mathrm{dF} / \mathrm{dx}) /\left(12 \pi \mathrm{r}_{\mathrm{b}} \mathrm{r}_{\mathrm{a}}^{3}\right)
$$

Stems of Pogonatum japonicum mostly approached a triangle in cross section. For this species we calculated I using

$\mathrm{I}=\mathrm{b} \cdot \mathrm{d}^{3} / 36 \quad$ (with $\mathrm{b}$ width, $\mathrm{d}$ height)

And used this in the calculation of EI and E.

Since the stems did not break during the test, calculation of breaking force $\mathrm{F}_{\text {max }}$ and stress at yield $\sigma$ was not possible.

\section{Statistical analysis}

As the data from several parameters were heteroscedastic, these were subjected to Ln- or Sqrt-transformation to ensure homoscedasticity (see tables 2, 4). One-way ANOVA (GLM) was used to test whether biomechanical tissue properties differed between sites differing in altitude. To investigate if these properties varied with altitudinal elevation we performed linear regressions with altitude ( $\mathrm{m}$ a.s.1.) as the independent variable (SPSS 22).

\section{RESULTS}

For both species at all altitudes there was much variation in biomechanical traits between individuals. Additionally, both species showed significant variation in all four parameters along the altitudinal gradients, but differences between samples from different altitudes were more obvious than any linear trends over the full length of the gradient (Figs. 1 and 2, Tables 1-4).

The Young's modulus $\left(\mathrm{E}_{\mathrm{b}}\right)$ decreased with altitude in Pogonatum japonicum (Fig. 1, Table 4), but did not show a consistent altitudinal trend in Pleurozium schreberi: the data of the site at $1260 \mathrm{~m}$ a.s.l. differed from those at 

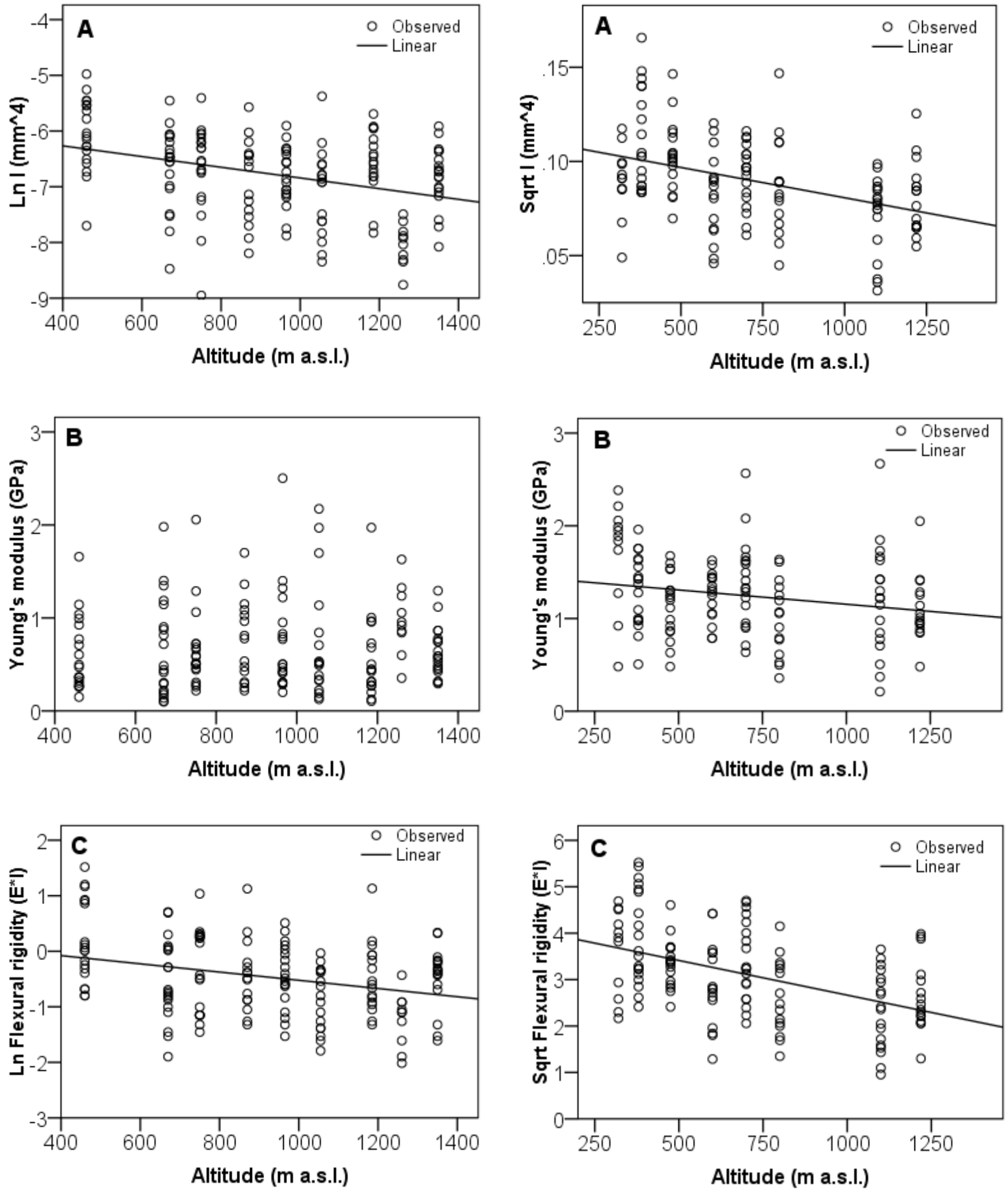

Fig. 1. Plots of (A) second moment of area I, (B) Young's modulus E, (C) flexural rigidity of stems of Pleurozium schreberi along an altitudinal gradient on Mt. Oakan, Hokkaido, Japan

Fig. 2. Plots of (A) second moment of area I, (B) Young's modulus E, (C) flexural rigidity of stems of Pogonatum japonicum along an altitudinal gradient on Mt. Eniwa, Hokkaido, Japan

the other altitudes (Fig. 2, Table 2). Second moment of area (I) and flexural rigidity $\left(\mathrm{E}^{*} \mathrm{I}\right)$ decreased with increasing altitude in both species.

Stems of Pogonatum were thicker (larger I) than those of Pleurozium and had a larger Young's modulus and flexural rigidity.

\section{DISCUSSION}

All three biomechanical traits of Pogonatum japonicum showed significant negative correlation with altitude, but for Pleurozium schreberi this applied only to second moment of area and flexural rigidity. The full sets of samples of both species showed a large amount of 
Table 2. Results of regressions against altitude and ANOVA for mechanical properties of Pleurozium schreberi on Mt. Oakan, Hokkaido, Japan. Data were transformed as indicated to make them homoscedastic.

$\begin{array}{lllll}\text { parameter } & \text { transformation } & \text { Significance } & \text { R square } & \text { R squared (GLM) } \\ \mathrm{I}\left(\mathrm{mm}^{4}\right) & \text { Ln } & \mathrm{P}<0.001 * * * & 0.118 & 0.309 \\ \text { Young's modulus }(\mathrm{MPa}) & \text { None } & \mathrm{P}<0.603 \text { n.s. } & 0.003 & 0.042 \\ \text { Flexural rigidity }(\mathrm{N} \mathrm{mm} 2) & \mathrm{Ln} & \mathrm{P}<0.001 * * * & 0.087 & 0.211\end{array}$

variation in these properties, but most of this represented variation between replicates. For most traits the differences between sites were substantial (the only exception being Young's modulus in P. schreberi) and only a small part of the variation was explained by altitude, as shown by the low R square for both species. Stems at different altitudes primarily seemed to vary in thickness, with consequently different values for second moment of area. Together with the gradual decrease in Young's modulus with increasing altitude in $P$. japonicum this may explain why flexural rigidity of the stems decreased for samples of this species collected at higher altitude. Stems of $P$. schreberi did not differ in Young's modulus with altitude.

Overall, in both species studied here shoots tended to be thinner (lower I) and less rigid (lower flexural rigidity) with increasing altitude, at least partially supporting our first hypothesis. It is tempting to speculate, that this pattern is related to altitudinal variation in growth conditions, with plants growing less well under the harsher conditions found at higher altitudes. These would include thickness and duration of snow cover, which will affect the length of the growing season as well as physically putting weight on the shoots. The large variation around the mean among and within the different sites observed in the study of Jägerbrand et al. (2014) as well as in this study indicates that plasticity in the physiological and biomechanical traits is large, perhaps larger than that due to difference in altitude. Size variation among shoots may be considerable at higher densities, however (e.g., Økland \& Økland 1996, Van der Hoeven \& During 1997), and it is possible that shoots of various sizes in dense turfs share the load of the snow cover, as Frenzke et al. (2011) seem to suggest. Regrettably, we did not collect data on plant traits such as shoot density and dry weight of individual shoots together with their bio- mechanical properties, nor environmental data such as duration and average depth of snow cover in winter along the altitudinal gradients.

A comparison of our results with those of previous studies is a bit difficult because of differences in methodology. Yet, in a study of biomechanics of sporophytes of some bryophytes in comparison with the properties of a range of vascular plants using Multiple Resonance Frequency Spectrum analysis (MRFS) Niklas (1995) found values for Young's modulus that were remarkably close to those of $P$. schreberi and P. japonicum in bending tests (Table 5). Values for Young's modulus of the plants of Fontinalis antipyretica studied by Biehle et al. (1998) using tension tests were also of the same order of magnitude (Table 5).

The stems of $P$. schreberi are more or less similar in thickness and structure to those of Hylocomium splendens (Ross et al., 1998). Young's modulus of the Pleurozium stems resembled that of the prostrate growth form of $H$. splendens as well, but it was less than that of the self-supporting plants of this species. In the study of Ross et al. (1998) too, most of the variation was found between replicates rather than between the two sites (which differed in latitude as well as in the growth form of the plants found there). Pogonatum japonicum is taxonomically and anatomically related to Dendroligotrichum dendroides (Frenzke et al., 2011), though the plants are much smaller than in that species. Young's modulus in $P$. japonicum was considerably lower than that in $D$. dendroides, but both species show rather higher values than are found in the other bryophytes studied so far (Table $5)$, most of which are characterized by more or less horizontally directed growth. This may be seen as support for our second hypothesis, but it may also simply reflect the phylogenetical constraints formed by the anatomy and the massive structure of the stems of the Polytrichaceae (Atala \& Alfaro, 2012).

Table 3. Summary of mechanical properties of Pogonatum japonicum on Mt. Eniwa, Hokkaido, Japan (averages \pm S.E.). E: Young's modulus; I: second moment of area; E*I: flexural rigidity.

$\begin{array}{lllll}\text { Alt }(\mathrm{m} \text { asl }) & \text { \#replicates } & \mathrm{E}(\mathrm{MPa}) & \mathrm{I}\left(\mathrm{mm}^{4}\right) & \mathrm{E} * \mathrm{I}(\mathrm{N} \mathrm{mm}) \\ 320 & 11 & 1702 \pm 174 & 0.0084 \pm 0.001 & 13.79 \pm 1.93 \\ 380 & 19 & 1291 \pm 88 & 0.013 \pm 0.0014 & 16.33 \pm 1.88 \\ 475 & 17 & 1132 \pm 85 & 0.0109 \pm 0.001 & 11.52 \pm 3.66 \\ 600 & 16 & 1247 \pm 67 & 0.0072 \pm 0.001 & 9.16 \pm 0.89 \\ 700 & 19 & 1379 \pm 108 & 0.0089 \pm 0.0007 & 12.27 \pm 1.36 \\ 800 & 15 & 1002 \pm 105 & 0.0081 \pm 0.0013 & 7.5 \pm 1.14 \\ 1100 & 18 & 1204 \pm 141 & 0.0055 \pm 0.0006 & 6.14 \pm 0.92 \\ 1219 & 16 & 1095 \pm 87 & 0.0068 \pm 0.0008 & 7.52 \pm 1.09\end{array}$


Table 4. Results of regressions against altitude and ANOVA for mechanical properties of Pogonatum japonicum on Mt. Eniwa, Hokkaido, Japan. Data were transformed as indicated to make them homoscedastic.

$\begin{array}{lllll}\text { parameter } & \text { transformation } & \text { Significance } & \text { R square } & \text { R square (GLM) } \\ \mathrm{I}\left(\mathrm{mm}^{4}\right) & \text { Sqrt } & \mathrm{P}<0.001 * * * & 0.159 & 0.262 \\ \text { Young's modulus }(\mathrm{MPa}) & \text { None } & \mathrm{P}<0.005^{* *} & 0.041 & 0.042 \\ \text { Flexural rigidity }(\mathrm{N} \mathrm{mm} 2) & \text { Sqrt } & \mathrm{P}<0.001 * * * & 0.215 & 0.294\end{array}$

The populations of $P$. schreberi on Mt. Oakan have also been used in studies of responses in growth and photosynthesis to temperature regimes connected with altitudinal variation and of the amount of genetic variation along the same gradient. In a growth chamber experiment employing three different temperature regimes, stems of $P$. schreberi from exactly the same sites sampled in our study were tested for responses in growth, branching and maximum quantum yield of photosynthesis (Jägerbrand et al., 2014). Just as in our study, much of the variation found was related to site rather than altitude, although length increment (under standard conditions) over a period of four weeks tended to increase in plants from higher altitudes. At all altitudes, populations consisted of several genotypes, with a positive relationship between genetic diversity and altitude (Korpelainen et al., 2012). This may indicate that differences in growth, physiology and biomechanical traits might partly be due to genetic variation.

Bryophytes have been shown to respond to factors associated with altitude in studies from several perspectives. First, most species are clearly restricted in the range of altitudes at which they grow (e.g., Lloret \& GonzálezMancebo, 2011; Ah-Peng et al., 2012). Populations at various altitudes may also differ in life history traits such as reproductive phenology and performance (Hassel et al., 2005a, c; Maciel-Silva et al., 2012) and in morphology, anatomy, growth and physiology (e.g., Zechmeister, 1995; Waite \& Sack, 2011). Altitudinal variation involves changes in many environmental factors (Körner, 2007), but most of these responses have been attributed to differences in temperature or associated water stress along the altitudinal gradient. These factors do not always provide a satisfactory explanation for the observed responses, however (Bader et al., 2013, Wagner et al., 2013). Transplant experiments have shown that differences between sites may be at least as large as differences connected with altitude, and suggest that genetic variation may partially underlie these patterns (Hassel et al., 2005b, Hedderson \& Longton, 2008). Perhaps this also applies to biomechanical traits such as Young's modulus, but addressing this question may require cultivation in a common garden experiment.

\section{ACKNOWLEDGMENTS}

AKJ would like to acknowledge support from the Japan Society for Promotion of Science (P07727), from Gaku Kudo and the Faculty of Environmental Earth Science, Hokkaido University. AKJ also thanks the officer at the Akan National Park for research permission to work in the area of Mt Oakan. We gratefully acknowledge the constructive comments of two anonymous reviewers.

Table 5. Average values (with, if applicable, standard deviation $\left(^{1}\right)$ or standard error $\left(^{2}\right)$ as given in the original publications) of Young's modulus E of sporophytes (Spor; mostly setae) or gametophyte stems (Gam) of some bryophytes differing in growth form and taxonomical position using pull tests (tension), bending tests or Multiple resonance frequency spectrum analysis (MRFS).

\begin{tabular}{|c|c|c|c|c|}
\hline name & $\mathrm{E}(\mathrm{MPa})$ & Spor/gam & method & source \\
\hline Anthoceros sp. & 735 & Spor & MRFS & Niklas 1995 \\
\hline Dicranum sp. & 165 & Spor & MRFS & Niklas 1995 \\
\hline Fissidens sp. & 87 & Spor & MRFS & Niklas 1995 \\
\hline Fontinalis sp. & 49 & Spor & MRFS & Niklas 1995 \\
\hline Polytrichum commune & 419 & Spor & MRFS & Niklas 1995 \\
\hline Polytrichum juniperinum & 256 & Spor & MRFS & Niklas 1995 \\
\hline Tortella sp. & 203 & Spor & MRFS & Niklas 1995 \\
\hline $\begin{array}{l}\text { Fontinalis antipyretica } \\
\text { in fast-flowing water } \\
\text { Fontinalis antipyretica }\end{array}$ & $633 \pm 171^{(1)}$ & Gam & tension & Biehle et al. 1998 \\
\hline $\begin{array}{l}\text { in slow-flowing water } \\
\text { Hylocomium splendens }\end{array}$ & $488 \pm 160^{(1)}$ & Gam & tension & Biehle et al. 1998 \\
\hline $\begin{array}{l}\text { self-supporting } \\
\text { Hylocomium splendens }\end{array}$ & $2591 \pm 245^{(2)}$ & Gam & bending & Ross et al. 1998 \\
\hline prostrate growth form & $718 \pm 70^{(2)}$ & Gam & bending & Ross et al. 1998 \\
\hline Dendroligotrichum dendroides & $4545 \pm 1355^{(1)}$ & Gam & bending & Frenzke et al. 2011 \\
\hline Pleurozium schreberi & $685 \pm 38^{(2)}$ & Gam & bending & This study \\
\hline Pogonatum japonicum & $1243 \pm 40^{(2)}$ & Gam & bending & This study \\
\hline
\end{tabular}




\section{LITERATURE CITED}

AH-PENG, C., N. WILDING, J. KLUGE, B. DESCAMPS-JULIEN, J. BARDAT, M. CHUAH-PETIOT, D. STRASBERG \& T.A.J. HEDDERSON. 2012. Bryophyte diversity and range size distribution along two altitudinal gradients: Continent vs. island. - Acta Oecologica 42: 58-65.

ATALA, C. \& J.F. ALFARO. 2012. Vascular architecture of the dendroid antipodean moss Dendroligotrichum dendroides (Brid. ex Hedw.) Broth. (Polytrichaceae). - Journal of Bryology 34: 277-280.

BADER, M., T. REICH, S. WAGNER, A.S. GONZÁLEZ GONZÁLEZ \& G. ZOTZ. 2013. Differences in desiccation tolerance do not explain altitudinal distribution patterns of tropical bryophytes. - Journal of Bryology 35: 47-56.

BIEHLE, G., T. SPECK \& H.C. SPATZ. 1998. Hydrodynamics and biomechanics of the submerged water moss Fontinalis antipyretica - a comparison of specimens from habitats with different flow velocities. Botanica Acta 111: 42-50.

FRENZKE, L., S. WANKE, S. ISNARD, A. STOLL, C. NEINHUIS \& N.P. ROWE. 2011. Stem biomechanics of the giant moss Dendroligotrichum dendroides s.l. and its significance for growth form diversity in mosses. - Journal of Bryology 33: 229-236.

GIMINGHAM, C.H. \& E.M. BIRSE. 1957. Ecological studies on growthform in bryophytes I. Correlations between growth-form and habitat. Journal of Ecology 45: 533-545.

GIVNISH, T.J. 1986. On the economy of plant form and function. - Cambridge, Cambridge Univ. Press. 717 pp.

HASSEL, K., B. PEDERSEN \& L. SÖDERSTRÖM. 2005a. Age and size at maturity in mountain and lowland populations of the expanding moss Pogonatum dentatum. - Plant Ecology 179: 207-216.

HASSEL, K., B. PEDERSEN \& L. SÖDERSTRÖM. 2005b. Changes in life-history traits in an expanding moss species: phenotypic plasticity or geneticdifferentiation? A reciprocal transplantation experiment with Pogonatum dentatum. - Ecography 28: 71-80.

HASSEL, K., S.M. SÅSTAD, U. GUNNARSSON \& L. SÖDERSTRÖM. $2005 \mathrm{c}$. Genetic variation and structure in the expanding moss Pogonatum dentatum (Polytrichaceae) in its area of origin and in a recently colonized area. - American Journal opf Botany 92: 1684-1690.

HEDDERSON, T.A. \& R.E. LONGTON. 2008. Local adaptation in moss life histories: population-level variation and a reciprocal transplant experiment. - Journal of Bryology 30: 1-11.

JÄGERBRAND, A.K., J.M. ALATALO \& G. KUDO. 2014. Variations in responses to temperature treatments ex situ of the moss Pleurozium schreberi (Willd. ex Brid.) Mitt. originating from eight altitude sites in Hokkaido, Japan. - Journal of Bryology 36: 209-216.

KIAEI, M. \& A. SAMARIHA. 2011. Relationship between altitude index and wood properties of Pinus eldarica Medw. (case study in north of Iran). - Gazi University Journal of Science 24: 911-918.
KÖRNER, C. 2007.The use of 'altitude' in ecological research. - Trends in Ecology and Evolution 22: 569-574.

KÖRNER, C. \& U. RENHARDT. 1987. Dry matter partitioning and root length/leaf area ratios in herbaceous perennial plants with diverse altitudinal distribution. - Oecologia 74: 411-418.

KÖRNER, C., P. BANNISTER \& A.F. MARK. 1986. Altitudinal variation in stomatal conductance, nitrogen content and leaf anatomy in different plant life forms in New Zealand. - Oecologia 69: 577-588.

KORPELAINEN, H., A. JÄGERBRAND \& M. VON CRÄUTLEIN. 2012. Genetic structure of mosses Pleurozium schreberi (Willd. ex Brid.) Mitt. and Racomitrium lanuginosum (Hedw.) Brid. along altitude gradients in Hokkaido, Japan. - Journal of Bryology 34: 309-312.

LLORET, F. \& J.M. GONZÁLEZ-MANCEBO. 2011. Altitudinal distribution patterns of bryophytes in the Canary Islands and vulnerability to climate change. - Flora 206: 769-781.

MACIEL-SILVA, A.S., I.F. MARQUES VALIO \& H. RYDIN. 2012. Altitude affects the reproductive performance in monoicous and dioicous bryophytes: examples from a Brazilian Atlantic rainforest. - AoB Plants 2012: pls016. $14 \mathrm{pp}$

NIKLAS, K.J. 1993. The scaling of plant height: a comparison among major plant clades and anatomical grades. - Annals of Botany 72: 165 172.

NIKLAS, K.J. 1994. The allometry of safety factors for plant height. American Journal of Botany 81: 345-351.

NIKLAS, K,J, 1995. Plant height and the properties of some herbaceous stems. - Annals of Botany 75: 133-142.

ØKLAND, R.H. \& T. ØKLAND. 1996. Population biology of the moss Hylocomium splendens in Norwegian boreal spruce forests. II. Effects of density. - Journal of Ecology 84: 63-69.

ROSS, S.E., T.V. CALLAGHAN, A.R. ENNOS \& E. SHEFFIELD. 1998. Mechanics and growth form of the moss Hylocomium splendens. Annals of Botany 82: 787-793.

ROSS, S.E., T.V. CALLAGHAN, M. SONESSON \& E. SHEFFIELD. 2001. Variation and control of growth-form in the moss Hylocomium splendens. - Journal of Bryology 23: 283-292.

VAN DER HOEVEN, E.C. \& H.J. DURING. 1997. The effect of density on size frequency distributions in chalk grassland bryophyte populations. - Oikos 80: 533-539.

WAGNER, S., G. ZOTZ, N. SALAZAR ALLEN \& M.Y. BADER. 2013. Altitudinal changes in temperature responses of net photosynthesis and dark respiration in tropical bryophytes. - Annals of Botany 111: 455-465.

WAITE, M. \& L. SACK. 2011. Shifts in bryophyte carbon isotope ratio across an elevation $x$ soil age matrix on Mauna Loa, Hawaii: do bryophytes behave like vascular plants? - Oecologia 166: 11-22.

ZECHMEISTER, H.G. 1995. Growth rates of five pleurocarpous moss species under various climatic conditions. - Journal of Bryology $\mathbf{1 8}$ : $455-468$. 